\title{
Effect of exogenous phytohormones and sucrose on micropropagation and microtuberisation of Manihot esculenta Crantz var. TMS 96/0023
}

\author{
Fotso $^{1,2_{*}}$, Elian Hubert Dieu Béni ${ }^{1,3}$, Tchouga Alvine Ornella $^{1}$, Djeuani Astride carole ${ }^{1,4}$, \\ Mbouobda Hermann Desire ${ }^{1,2}$ and Omokolo Ndoumou Denis ${ }^{1}$
}

${ }^{1}$ Laboratory of Plant Physiology, Higher Teacher's Training College, University of Yaoundé 1. P.O. Box 47, Yaoundé, Cameroon.

${ }^{2}$ Department of Biology, Higher Teachers Training College Bambili, University of Bamenda, P.O. Box 39 Bamenda, Cameroon.

${ }^{3}$ Department of Biology, Faculty of Sciences, University of Bangui, P.O. Box 1450 Bangui, Central African Republic. ${ }^{4}$ Department of plant Biology, Faculty of Sciences, University of Yaoundé I, P.O. Box 824 Yaoundé, Cameroon.

Received 22 May, 2014; Accepted 22 September, 2014

\begin{abstract}
The effect of exogenous phytohormones and sucrose on micropropagation and microtuberization from nodal cuttings of Manihot esculenta was studied. Direct and indirect organogeneses were established from these explants. When nodal cuttings were cultured in the presence of 0.01 to $0.1 \mathrm{mg}^{-1} \mathrm{~L}^{-1}$ of BAP or NAA there was induction of the budding of axillary buds, with the highest percentages of nodal cuttings with axillaries buds budded of 98 and $73 \%$ with $0.07 \mathrm{mg}^{-1} \mathrm{~L}^{-1}$ BAP and $0.05 \mathrm{mg} \cdot \mathrm{L}^{-1} \mathrm{NAA}$, respectively. When sub cultured in the presence of 0.05 to $0.1 \mathrm{mg} \cdot \mathrm{L}^{-1} \mathrm{NAA}$, the nodal cuttings with axillaries buds budded produced yellowish and friable callus with the highest percentage of callogenesis of $59.8 \%$ with $0.08 \mathrm{mg} \cdot \mathrm{L}^{-1} \mathrm{NAA}$. The highest fresh weight of callus of $1334.7 \mathrm{mg}$ was obtained with $0.07 \mathrm{mg} \cdot \mathrm{L}^{-1}$ of NAA. When sub cultured in the presence of 0.05 to $0.1 \mathrm{mg} \cdot \mathrm{L}^{-1} \mathrm{BAP}$, the nodal cuttings and callus induced shoots with the highest percentages of $72.3 \%$ and $92.3 \%$ for nodal cutting and callus respectively with $0.08 \mathrm{mg} \cdot \mathrm{L}^{-1}$. Also, the highest numbers of shoots per nodal cutting 17.9 and per callus 28.1 were obtained with $0.08 \mathrm{mg} \cdot \mathrm{L}^{-1}$. Multiple shoots, when isolated from nodal cuttings or callus and sub cultured in the presence of different ratio of BAPINAA, differentiated into plantlets. With $0.07 / 0.05 \mathrm{mg} \cdot \mathrm{L}^{-1}$ and $0.08 / 0.05 \mathrm{mg} \mathrm{l}^{-1}$ ratio, all shoots $(100 \%)$ gave rise to plantlets with the highest growth parameters (14.8 \pm 3.1 to $15.3 \pm 1.7 \mathrm{~cm}$ of high, 12.3 to 12.7 leaves and 7.8 to 8.3 roots). These plantlets were used to induce microtubers on the basal medium supplemented with 0.1 to $0.6 \mathrm{mg} \cdot \mathrm{L}^{-1}$ of NAA or Kin or NAA/Kin ratio and 10 to $60 \mathrm{~g} \cdot \mathrm{L}^{-1}$ sucrose. The ratio NAA/Kin of $0.4 / 0.4 \mathrm{mg} \cdot \mathrm{L}^{-1}$ combined with 20 to $30 \mathrm{~g} \cdot \mathrm{L}^{-1}$ sucrose was more effective on the microtuberization than NAA and Kin used separately. In fact, it gave rise to 57.8 to 61.3\% of plantlets which produce microtubers with the highest number of microtuber per plantlet (4 to 5), the highest diameter (130.4 to $131.8 \mathrm{~mm}$ ) and the highest fresh weight of microtubers (403.3 to 408.1 $\mathrm{mg})$. When the plantlets were acclimatized in different substrates, $100 \%$ survived in the mixture red soil/black soil at equal volume (V/V) These results of this work show that BAP, NAA, and Kin used separately or in ratio can be used for organogenesis and micropropagation in Manihot esculenta var TMS 96/0023 in vitro.
\end{abstract}




\section{INTRODUCTION}

Cassava (Manihot esculenta Crantz) is a major staple crop for millions of people in East and Central Africa, mostly in the rural areas and it is the second most important staple crop in Africa after maize. Because of it importance in food security and poverty alleviation, cassava has been prioritized by the New Partnership for Africa's Development (NEPAD) as a 'poverty fighter' which will spur industrial development in Africa (Whingwiri, 2004). Acedo and Labana (2008) reported that the demand for cassava has been increase in the recent past years because of its potential use in biofuel industry. It is grown for its starchy tuberous roots which provide food for over 500 million people, mostly in a small-scale plantation by the farmers in the developing countries (Roca et al., 1992). Thus, anything that affects the production of the cassava crop may have serious consequences in food availability and the economy of the people in such growing areas. It is therefore not surprising that every year millions of dollars are allocated by the government in these growing areas to combat pests and diseases which affect the yields of the crop. Some challenges of cultivation include low nutritive value of cassava (1.2 to $1.8 \%$ crude protein, 0.1 to $0.8 \%$ crude lipid, 1.5 to $3.5 \%$ crude fiber and 1.3 to $2.8 \%$ ash) (Albert et al., 2005) and occasionally accumulations of toxic cyanogenic glucosides (White et al., 1998). This therefore, necessitates the adoption of breeding programmes to introduce new varieties of higher nutritional quality.

Tissue culture is one of the most successful, comercially exploited components of biotechnology and has been used for rapid clonal multiplication (micropropagation) of selected genotypes of diverse groups of plant species (Rani and Raina, 2000). The first study on tissue culture of cassava was done by Kartha et al. (1974) who reported regeneration of shoots from meristems of five cassava varieties cultured on MS medium supplemented with $0.1 \mathrm{mg} \cdot \mathrm{L}^{-1}$ Benzylaminopurine (BAP), $0.04 \mathrm{mg} \cdot \mathrm{L}^{-1}$ Gibberellic acid (GA3) and $0.2 \mathrm{mg} \cdot \mathrm{L}^{-1}$ Naphylacetic acid (NAA). Bhagwat et al. (1996) reported regeneration of multiple shoots from nodal explants of cassava using 0.11 to $0.22 \mu \mathrm{M} . \mathrm{L}^{-1}$ thidiazuron (TDZ), $2.2 \mu \mathrm{M} . \mathrm{L}^{-1} \mathrm{BAP}$ and $1.6 \mu \mathrm{M} . \mathrm{L}^{-1} \mathrm{GA} 3$. A frequent in vitro culture manipulation for cassava involves standard media such as the Murashige and Skoog (1962) (MS medium), but with altered macroand/or micronutrient concentrations. This manipulation was initially restricted to embryo culture and nodal micro propagation, but was later extended to somatic embryogenesis (Taylor et al., 1996).

The aim of this study was to test the effect of exoge- nous phytohormones concentration and sucrose on micropropagation and microtuberisation of cassava. Many factors such as the presence or the absence of growth regulators, the concentration and of sugars, the mineral composition of the medium and the photoperiod were known to influence the organogenesis in vitro (Koda and Kikuta, 1991; Mantell and Hugo, 1989; Santos and Salema, 2000; Ovono Ondo et al., 2007). Therefore, the effect of growth regulators (BAP and NAA) and sucrose, together or in combination with the micropropagation of $M$. esculenta was studied.

\section{MATERIALS AND METHODS}

\section{Plant material and disinfection}

TMR 96/0023 cassava variety was obtained from the Internal Institute of Tropical Agriculture (IITA) PMB 2008, Messa Yaounde, Cameroon. Nodal cuttings (explants) for $1.5 \mathrm{~cm}$ long were isolated from stems of this variety and then, cleaned under running tap water for $2 \mathrm{~h}$. These explants were disinfected in $70 \%$ ethanol for 5 min followed by $3.5 \%$ sodium hypochlorite for $10 \mathrm{~min}$ and then rinsed four times (10 min each) in sterilized distilled water. All stages of disinfection were done in the laminar flow hood.

\section{Budding of axillaries buds from nodal cuttings}

For all experiments the basal medium (BM) consists of Murashige and Skoog (MS) salt (1962) supplemented with Morel and Wetmore (1951) vitamins, $20 \mathrm{~g} . \mathrm{L}^{-1}$ sucrose and $7 \mathrm{~g}^{-\mathrm{L}^{-1}}$ Difco agar. For the budding of axillaries buds, disinfected nodal cuttings were cultured in closed test tubes containing $10 \mathrm{ml}$ of BM supplemented with 0.01 to $0.1 \mathrm{mg} \cdot \mathrm{L}^{-1}$ of 6 - benzylaminopurine (BAP) or 0.01 to $0.1 \mathrm{mg} \cdot \mathrm{L}^{-1}$ of naphthalene acetic acid (NAA). The $\mathrm{pH}$ of all media was adjusted to 5.8 with $\mathrm{NaOH}$ solution $(1 \mathrm{~N})$ or $\mathrm{HCl}$ solution $(0.1 \mathrm{~N})$ before autoclaving at $115^{\circ} \mathrm{C}$ for $30 \mathrm{~min}$ under a pressure of $1.6 \pm 0.1$ $\mathrm{kg} . \mathrm{cm}^{-2}$. All cultures were incubated under $80 \mu \mathrm{mol} . \mathrm{m}^{-2} \cdot \mathrm{s}^{-1}$ light provided by cool white fluorescent tube lamps (Mazda) at a photoperiod of $16 \mathrm{~h}$ at $26 \pm 1{ }^{\circ} \mathrm{C} .100$ nodal cuttings were cultured for each medium and the experiment was repeated twice. After 11 days, axillaries buds develop and the percentage of budding was calculated per medium. The nodal cutting with budded axillaries buds constituted the explants for the following experiments.

\section{Induction of callus from nodal cuttings}

For the induction of callus, the nodal cuttings with budded buds were sub cultured in the closed test tubes $(150 \times 80 \mathrm{~mm})$ containing $10 \mathrm{ml}$ of BM supplemented with 0.05 to $0.1 \mathrm{mg} \cdot \mathrm{L}^{-1} \mathrm{NAA}$. The $\mathrm{pH}$ of all media was adjusted to 5.8 before autoclaving. All sub cultures were incubated under the same conditions as during budding of axillaries buds. 50 explants were sub cultured per

${ }^{*}$ Corresponding author. E-mail: mbouobda@yahoo.fr.

Abbreviations: BAP: Benzylaminopurine, NAA: Naphthalene Acetic Acid, Kin: Kinetin, etc

Author(s) agree that this article remain permanently open access under the terms of the Creative Commons Attribution License 4.0 International License 
medium and the experiment was repeated thrice. The percentages of explants inducing callus and the fresh weight of callus were evaluated per medium after 28 days. For all experiments, the control was the BM without phytohormones.

Induction and proliferation of multiple shoots from nodal cuttings or from callus

The effect of BAP on the induction and proliferation of multiple shoots was tested directly by using nodal cuttings with budding auxiliary buds or indirectly by using callus as explants. For direct method, nodal cuttings were sub cultured in BM supplemented with 0.05 to $0.1 \mathrm{mg} . \mathrm{L}^{-1} \mathrm{BAP}$. The $\mathrm{pH}$ of all media was adjusted to 5.8 before autoclaving. All sub cultures were incubated under the same conditions as during budding of axillaries buds. 50 explants were sub cultured per medium and the experiment was repeated thrice. The percentage of explants inducing multiple shoots and the average number of shoots per explant were evaluated per medium after 45 days.

For indirect method, callus induced in the presence of NAA were first sub cultured in basal medium without phytohormones for 7 days. This sub culture was followed by a second sub culture in BM supplemented with 0.05 to $0.1 \mathrm{mg} \cdot \mathrm{L}^{-1} \mathrm{BAP}$. Also, the $\mathrm{pH}$ of all media was adjusted to 5.8 before autoclaving. All second sub cultures were incubated under the same conditions as during induction of callus. 50 callus were sub cultured per medium and the experiment was repeated thrice. The percentage of callus inducing multiple shoots and the average number of shoots per callus were evaluated per medium after 45 days. For all experiments, the control was the BM without phytohormones.

\section{Regeneration of plantlets from multiple shoots}

For the regeneration of plantlets, multiple shoots were isolated from different explants (nodal cuttings and callus) and cultured firstly for 7 days in closed test tubes containing each $10 \mathrm{ml}$ of basal medium and secondly on the basal medium supplemented with 0.05 to 0.1 mg. $\mathrm{L}^{-1}$ BAP and $0.05 \mathrm{mg} . \mathrm{L}^{-1} \mathrm{NAA}$ (BAP / NAA ratio) (Table 3). The $\mathrm{pH}$ of all media was adjusted to 5.8 before autoclaving. All cultures were incubated under the same conditions as during budding of axillaries buds. 30 isolated multiple shoots were cultured per medium and the experiments was repeated thrice. The growth of plantlets was measured after 26 days by counting the number of leaves and roots differentiated and by measuring the height of plantlets in the presence of each BAP/NAA ratio. The control medium was the BM without phytohormones.

\section{Induction and growth of microtubers}

Regenerated plantlets from multiple shoots were subcultured in closed test tubes containing each $10 \mathrm{ml}$ of semi liquid $\left(3.5 \mathrm{~g} \cdot \mathrm{L}^{-1}\right.$ Difco agar) basal medium supplemented with $2 \mu \mathrm{M}$ Jasmonic acid, 0.1 to $0.6 \mathrm{mg} \mathrm{l}^{-1} \mathrm{NAA}$ or Kinetin (Kin) or 0.1 to $0.6 \mathrm{mg} \cdot \mathrm{L}^{-1} \mathrm{NAA}$ and $0.4 \mathrm{mg} . \mathrm{L}^{-1} \mathrm{Kin}$ (NAA/Kin ratio) (Table 4) The $\mathrm{pH}$ of all media was adjusted to 5.8 before autoclaving. All cultures were incubated under the same conditions as during plantlets regeneration. 20 plantlets were sub cultured for each concentration of phytohormones or each ratio and all experiments were repeated thrice. After 65 days, the percentage of plantlets inducing microtubers, the average number of microtubers produced, the average diameter and the average fresh weight of microtubers were evaluated for each treatment. For all experiments, control was the semi liquid basal medium without phytohormones. Simultaneously the effect of sucrose on the inducing and growth of microtubers was also studied. The semi liquid basal medium was supplemented with 10 , $20,30,40,50$ and $60 \mathrm{~g} \cdot \mathrm{L}^{-1}$ sucrose together with $0.4 \mathrm{mg} \cdot \mathrm{L}^{-1} \mathrm{NAA}$ or Kin or $0.4 / 0.4 \mathrm{mg} . \mathrm{L}^{-1} \mathrm{NAA} / \mathrm{Kin}$. The control was the semi liquid basal medium without phytohormones.

\section{Acclimatization of plantlets}

Some regenerated plantlets from multiple shoots were acclimatized in polyethylene bags containing the following sterilized substrates; red soil, black soil, vermiculite, mixture red soil/ black soil at equal volume $(\mathrm{V} / \mathrm{V})$, red soil/vermiculite $(\mathrm{V} / \mathrm{V})$, and black soil/vermiculite (V/V). However, the effects of these substrates were tested for acclimatization, 20 plantlets were cultured per substrate and the experiment was repeated thrice. All cultures were incubated under a temperature of $26 \pm 1^{\circ} \mathrm{C}, 70$ to $72 \%$ of relative humidity and a photoperiod of 16 under a light period of $80 \mu \mathrm{mol} . \mathrm{m}^{-2} . \mathrm{s}^{-1}$ during 36 days. During this period, the relative humidity was progressively reduced as plantlets were watered firstly with sterilized tap water during 10 days and then with tap water during 26 days. The percentage of survival was evaluated per substrate.

\section{Data analysis}

All experiments were set up in a completely randomized design. Differences between means were scored with Duncan's Multiplication Range Test. The analysis of samples from each treatment was statically evaluated by analysis of variance (ANOVA, $P<0.05$ ) and the interactive effect of two phytohormones was assessed by twoway ANOVA. The program used was SPSS (version 12 for windows).

\section{RESULTS}

\section{Effect of BAP and NAA on budding of axillaries buds of nodal cuttings}

Nodal cuttings were cultured (Figure 1a) in the presence of 0.01 to $0.1 \mathrm{mg}^{-L^{-1}}$ of BAP or NAA for inducing the budding of axillaries buds. After 11 days of culture, the highest percentages of nodal cuttings with axillaries buds budded were 98 and $73 \%$ with 0.07 and 0.03 mg. $\mathrm{L}^{-1}$ BAP and NAA respectively (Figure 2 ). The lowest percentages of 59 and $17 \%$ were obtained with $0.1 \mathrm{mg} \cdot \mathrm{L}^{-1}$ of both phytohormones (Figure 2). Comparatively, BAP is more effective on the budding than NAA. In fact, the percentages of budding obtained with BAP at all concentrations were higher than that of NAA (Figure 2). The budding is mainly characterized by increasing the volume and elongation of axillaries buds (Figure 1b).

\section{Effect of NAA on the production and growth of callus from budded nodal cuttings}

When cultured in the basal medium supplemented with 0.05 to $0.1 \mathrm{mg} \cdot \mathrm{L}^{-1} \mathrm{NAA}$, the budded nodal cuttings produced callus after 28 days. These callus were yellowish and friable (Figure 1c). The highest percentage of callogenesis $(59.8 \%)$ was obtained with $0.08 \mathrm{mg} \cdot \mathrm{L}^{-1}$ 

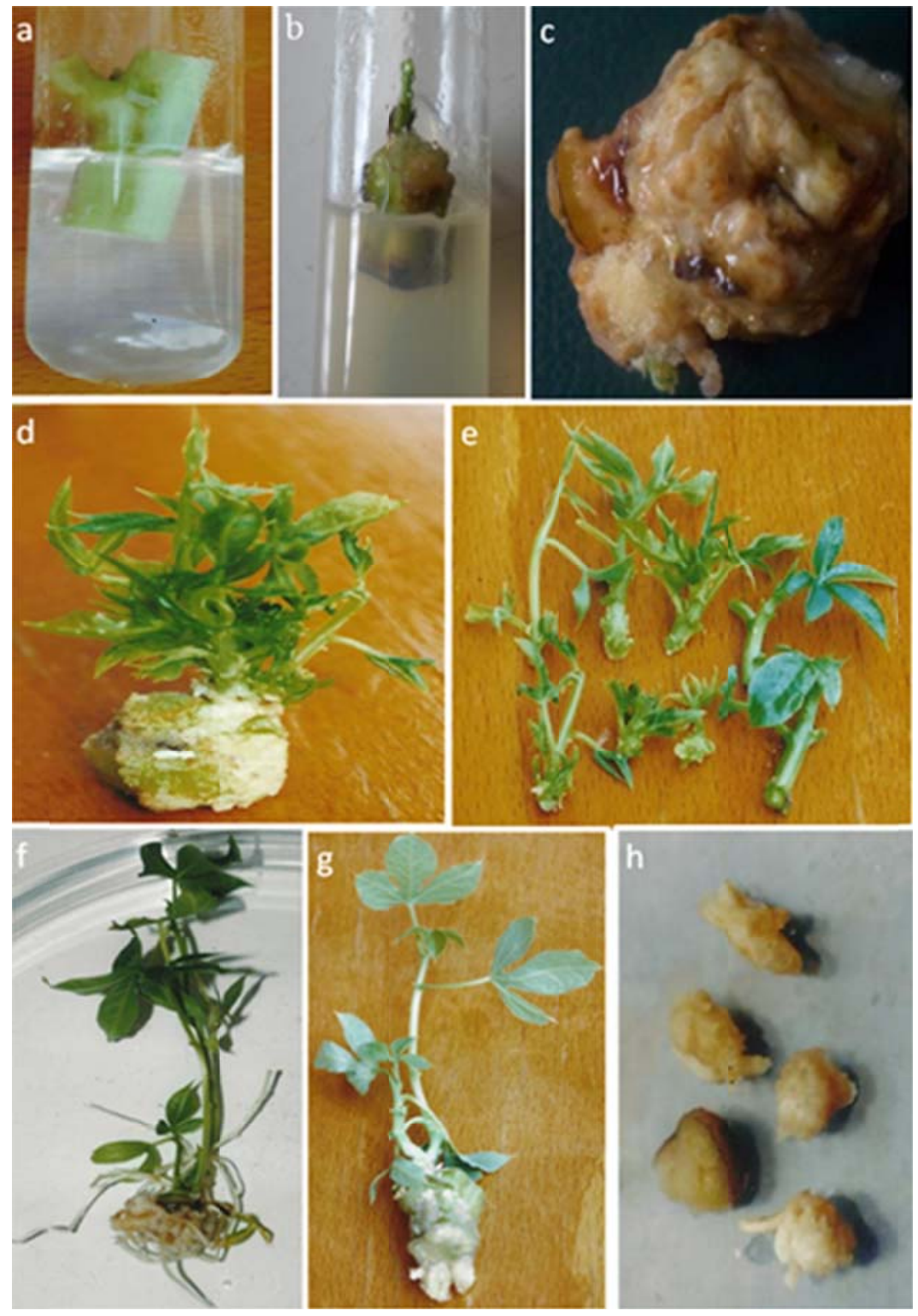

Figure 1. Micropropagation and microtuberization of Manihot esculenta. (a) Nodal cutting cultured on BM supplemented with 0.01 to $0.1 \mathrm{mg} \cdot \mathrm{L}^{-1}$ BAP or NAA; (b) budded axillary buds after 11 days of culture on the same media; (c) callus produced from nodal cutting after 28 days of culture on BM supplemented with $0.08 \mathrm{mg} . \mathrm{L}^{-1} \mathrm{NAA}$; (d) multiple shoots differentiated on callus after 45 days of culture on BM supplemented with $0.08 \mathrm{mg} \cdot \mathrm{L}^{-1} \mathrm{BAP}$; (e) isolated shoots from nodal cuttings or from callus ; (f) Plantlets regenerated from shoots after 26 days of culture on BM supplemented with $0.07 / 0.05$ or $0.08 / 0.05$ g. $\mathrm{L}^{-1}$ BAP/NAA; $(\mathrm{g})$ microtubers $(\mathrm{mc}$ ) induced on plantlets sub cultured on BM supplemented with $0.4 / 0.4 \mathrm{NAA} / \mathrm{Kin}$ and $30 \mathrm{~g} \cdot \mathrm{L}^{-1}$ sucrose after 35 days of culture; $(\mathrm{h})$ isolated microtubers from plantlets after 65 days of culture.

NAA (Table 1). The fresh weight of callus varied with the concentration of NAA. The highest fresh weights of $1344.7 \mathrm{mg}$ and $1337.4 \mathrm{mg}$ were obtained with 0.07 and $0.08 \mathrm{mg} . \mathrm{L}^{-1}$ of NAA respectively (Table 1 ). With the other concentrations, the value of fresh weight was between $529.3 \mathrm{mg}$ and $1023.2 \mathrm{mg}$ (Table 1).

\section{Effect of BAP on the induction of shoots from nodal cuttings and callus}

When cultured in the presence of 0.05 to $0.1 \mathrm{mg} \cdot \mathrm{L}^{-1} \mathrm{BAP}$, the nodal cuttings induce shoots after 30 days and the callus after 45 days (Figure 1d). The percentages of 


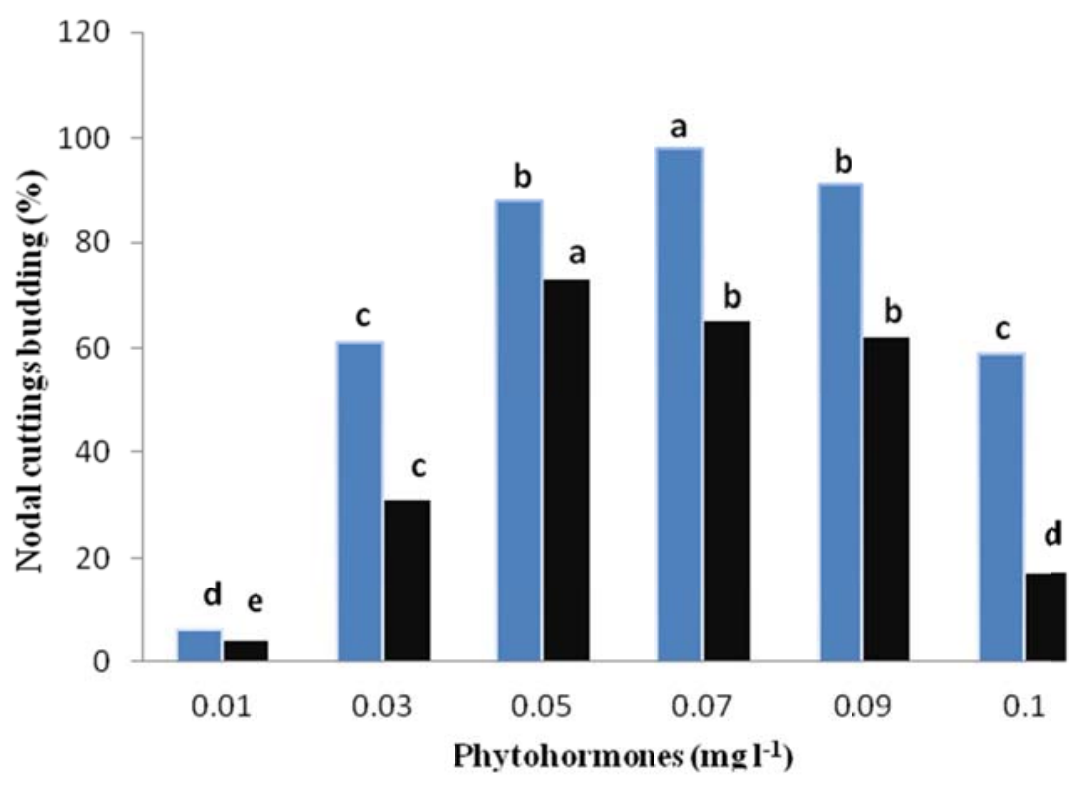

Figure 2. Effect of BAP( $\square$ ) and NAA ( $\mid$ ) on budding of axillaries buds of nodal cuttings of Manihot esculenta after 11 days of culture. DMRT was used to differentiate the percentage of axillaries buds budding. For each treatment the share carrying the same letter were not significantly different at $5 \%$ level.

Table 1. Effect of NAA on the callogenesis and fresh weight of callus from nodal cuttings with budded axillary buds of Manihot esculenta after 28 days of culture.

\begin{tabular}{lcc}
\hline $\begin{array}{l}\text { NAA } \\
\left(\mathbf{m g} \cdot \mathbf{L}^{-\mathbf{1}}\right)\end{array}$ & $\begin{array}{c}\text { \% of } \\
\text { callogenesis }\end{array}$ & $\begin{array}{c}\text { Average fresh weight } \\
\text { of callus }(\mathbf{m g})\end{array}$ \\
\hline 0 & 0 & 0 \\
0.05 & $3.6^{\mathrm{f}}$ & $801.5^{\mathrm{c}}$ \\
0.06 & $15.4^{\mathrm{e}}$ & $1023.2^{\mathrm{b}}$ \\
0.07 & $28.3^{\mathrm{c}}$ & $1344.7^{\mathrm{a}}$ \\
0.08 & $59.8^{\mathrm{a}}$ & $1337.4^{\mathrm{a}}$ \\
0.09 & $31.4^{\mathrm{b}}$ & $648.8^{\mathrm{d}}$ \\
0.1 & $17.2^{\mathrm{d}}$ & $529.3^{\mathrm{e}}$ \\
\hline
\end{tabular}

DMRT was used to differentiate the percentages of callogenesis and the fresh weight of callus. Data carrying the same letter in the same column were not significantly different at $5 \%$ level.

explants inducing shoots and the average number of shoots per explants varied according to the concentration of BAP and the type of explants. The highest percentages of $72.3 \%$ and $92.3 \%$ were obtained respectively with nodal cutting and callus with $0.08 \mathrm{mg} \cdot \mathrm{L}^{-1} \mathrm{BAP}$ and the lowest percentages of $12.4 \%$ for nodal cuttings and $13.3 \%$ for callus were obtained with $0.06 \mathrm{mg}^{-1} \mathrm{~L}^{-1}$ and 0.05 mg. $\mathrm{L}^{-1}$ BAP respectively (Table 2 ). Also the highest numbers of shoots per nodal cutting (17.9) and per callus (26.8 to 28.1) were obtained with $0.08 \mathrm{mg}^{-\mathrm{L}^{-1}}$ and 0.07 $\mathrm{mg} \cdot \mathrm{L}^{-1}$, respectively (Table 2 ). When compare the performance of explants to induce shoots, callus was more effective than nodal cuttings. In fact the percentages of callus inducing shoot and the average numbers of shoots per callus were generally higher than that of Nodal cutting almost for all concentrations of BAP tested (Table 2).

\section{Effect of BAP I NAA ratio on the regeneration and growth of plantlets from multiple shoots}

When isolated from nodal cuttings or callus (Figure 1e) and sub cultured in the presence of different ratio of BAP/NAA, the multiple shoots gave rise to plantlets (Figure 1f) after 26 days. With $0.07 / 0.05$ and $0.08 / 0.05$ mg. $\mathrm{L}^{-1}$ ratio, all shoots $(100 \%)$ gave rise to plantlets (Table 3). Also with these ratio, plantlets had the highest height $(14.7 \pm 3.6$ to $15.3 \pm 1.7 \mathrm{~cm})$, the highest number of leaves (11.9 to 12.7) and the highest number of roots (7.8 to 8.3) (Table 2). The lowest parameters of regeneration (percentage of differentiation, $21 \%$ to $31 \%$; height of plantlets, $9.6 \mathrm{~cm}$ to $11.2 \mathrm{~cm}$; number of leaves, 4.1 to 7.1 and number of roots, 3.3 to 4.5 ) were obtained with $0.05 / 0.05$ and $0.1 / 0.05 \mathrm{mg}^{-\mathrm{L}^{-1}}$ BAP/NAA (Table 3 ).

\section{Effect of NAA, Kin and NAA/Kin ratio on the production and growth of microtubers from plantlets}

When sub cultured in the basal medium supplemented with NAA or Kin or NAA/Kin ratio, the plantlets differentiate microtubers at their base in 35 days (Figure $1 \mathrm{~g})$. These microtubers grew and after 65 days, they 
Table 2. Effect of BAP on the inducing of shoots from nodal cuttings and callus of Manihot esculenta after 45 days of culture.

\begin{tabular}{lcccc}
\hline \multirow{2}{*}{ BAP $\left(\mathbf{m g} \cdot \mathbf{L}^{-1}\right)$} & \% of explants inducing shoots & \multicolumn{2}{c}{ Average number of shoots } & per explants \\
\cline { 2 - 5 } & Nodal cuttings & Callus & Nodal cuttings & Callus \\
\hline 0 & 0 & 0 & 0 & 0 \\
0.05 & 0 & $13.3^{\mathrm{f}}$ & 0 & $4.0^{\mathrm{c}}$ \\
0.06 & $12.4^{\mathrm{e}}$ & $22.2^{\mathrm{e}}$ & $3.2^{\mathrm{c}}$ & $1.6^{\mathrm{d}}$ \\
0.07 & $61.8^{\mathrm{b}}$ & $71.7^{\mathrm{b}}$ & $8.4^{\mathrm{b}}$ & $26.8^{\mathrm{a}}$ \\
0.08 & $72.3^{\mathrm{a}}$ & $92.3^{\mathrm{a}}$ & $17.9^{\mathrm{a}}$ & $28.1^{\mathrm{a}}$ \\
0.09 & $44.1^{\mathrm{c}}$ & $51.9^{\mathrm{c}}$ & $7.8^{\mathrm{b}}$ & $5.8^{\mathrm{b}}$ \\
0.1 & $23.3^{\mathrm{d}}$ & $36.7^{\mathrm{d}}$ & $4.2^{\mathrm{c}}$ & $6.1^{\mathrm{b}}$ \\
\hline
\end{tabular}

DMRT was used to differentiate the percentage of explants inducing shoots and the average number of shoots per explants. Data carrying the same letter in the same column were not significantly different at $5 \%$ level.

Table 3. Effect of BAP/NAA ratio on the regeneration and growth of plantlets from isolated shoots of Manihot esculenta after 26 days of culture.

\begin{tabular}{lcccc}
\hline BAP/NAA (mg. $\left.\mathbf{L}^{-1}\right)$ & $\begin{array}{c}\text { \% of shoots } \\
\text { growth to plantlets }\end{array}$ & $\begin{array}{c}\text { Height of plantlets } \\
(\mathbf{c m})\end{array}$ & $\begin{array}{c}\text { Average number of leaves } \\
\text { per plantlets }\end{array}$ & $\begin{array}{c}\text { Average number of roots } \\
\text { per plantlets }\end{array}$ \\
\hline 0 & 0 & 0 & 0 & 0 \\
$0.05 / 0.05$ & 21 & $9.6 \pm 3.1^{\mathrm{d}}$ & $4.1^{\mathrm{d}}$ & $3.3^{\mathrm{d}}$ \\
$0.06 / 0.05$ & 68 & $12.2 \pm 2.8^{\mathrm{b}}$ & $6.0^{\mathrm{c}}$ & $5.6^{\mathrm{b}}$ \\
$0.07 / 0.05$ & 100 & $14.7 \pm 3.6^{\mathrm{a}}$ & $11.9^{\mathrm{a}}$ & $8.3^{\mathrm{a}}$ \\
$0.08 / 0.05$ & 100 & $15.3 \pm 1.7^{\mathrm{a}}$ & $12.7^{\mathrm{a}}$ & $7.8^{\mathrm{a}}$ \\
$0.09 / 0.05$ & 48 & $14.8 \pm 3.1^{\mathrm{a}}$ & $12.3^{\mathrm{a}}$ & $4.1^{\mathrm{a}}$ \\
$0.1 / 0.05$ & 31 & $11.2 \pm 3.3^{\mathrm{c}}$ & $7.1^{\mathrm{b}}$ & $4.5^{\mathrm{c}}$ \\
\hline
\end{tabular}

$\mathrm{X}^{2}$ and DMRT were used to differentiate the height of plantlets, the average number of leaves and average number of roots per plantlets. Data carrying the same letter in the same column were not significantly different at $5 \%$ level.

were isolated from plantlets (Figure $1 \mathrm{~h}$ ) and weighed. The percentages of plantlets producing microtubers, the number of microtubers per plantlet, their diameter and fresh weight varied with the type and the concentrations of phytohormones. The highest percentage of plantlets producing microtubers $(57.6 \%)$ was obtained with $0.4 / 0.4$ $\mathrm{mg} \cdot \mathrm{L}^{-1} \mathrm{NAA} / \mathrm{Kin}$; follow by $0.4 \mathrm{mg} \cdot \mathrm{L}^{-1} \mathrm{NAA}(34.6 \%)$ and by $0.4 \mathrm{mg} . \mathrm{L}^{-1} \mathrm{Kin}(33.2 \%)$ (Table 4$)$. The number of microtubers per plantlet varied from 1 to 4 for all treatments (Table 4). The microtubers with the highest diameter $(108.4 \mathrm{~mm})$ were obtained with $0.4 / 0.4 \mathrm{NAA} / \mathrm{Kin}$ ratio; follow by $0.4 \mathrm{mg} . \mathrm{L}^{-1} \mathrm{Kin}(61.3 \mathrm{~mm})$ and by 0.3 and 0.4 mg. L $^{-1}$ NAA $(55.8 \mathrm{~mm})$ (Table 4). With all other treatments, the diameter of microtubers was below these higher values (Table 4). The highest fresh weights of microtubers (326.9 mg and $320.4 \mathrm{mg}$ ) were obtained with $0.4 / 0.4 \mathrm{mg} \cdot \mathrm{L}^{-1}$ and $0.3 / 0.4 \mathrm{mg} \cdot \mathrm{L}^{-1} \mathrm{NAA} / \mathrm{Kin}$, follow by 0.4 and $0.3 \mathrm{mg}^{-1} \mathrm{~L}^{-1} \mathrm{Kin}$ (284.1 and $248.6 \mathrm{mg}$, respectively) and by $0.2 \mathrm{mg} \mathrm{l}^{-1} \mathrm{NAA}(248.3 \mathrm{mg}$ ) (Table 4). The lowest fresh weights of microtubers $(151.2 \mathrm{mg}, 195.6 \mathrm{mg}$ and $154.1 \mathrm{mg}$ ) were obtained with $0.1 \mathrm{mg} \cdot \mathrm{L}^{-1} \mathrm{NAA} ; 0.6 \mathrm{mg} \cdot \mathrm{L}^{-1}$ Kin and 0.1/0.4 mg. $\mathrm{L}^{-1} \mathrm{NAA} /$ Kin respectively (Table 4).

\section{Effect of sucrose on the production and growth of microtubers from plantlets}

When plantlets were sub cultured in the presence of 10 to $60 \mathrm{~g} . \mathrm{L}^{-1}$ sucrose supplemented with $0.4 \mathrm{mg} \cdot \mathrm{L}^{-1} \mathrm{NAA}$ or $0.4 \mathrm{mg} \cdot \mathrm{L}^{-1} \mathrm{Kin}$ or $0.4 / 0.4 \mathrm{mg} \cdot \mathrm{L}^{-1} \mathrm{NAA} / \mathrm{Kin}$, they differentiated microtubers in 35 days. They were then harvested after 65 days and Weighed. The highest percentages of plantlets producing microtubers (61.3 and $41.2 \%$ ) were obtained with $30 \mathrm{~g} \cdot \mathrm{L}^{-1}$ sucrose in the presence of $0.4 / 0.4 \mathrm{mg} \cdot \mathrm{L}^{-1} \mathrm{NAA} / \mathrm{Kin}$ and $0.4 \mathrm{mg} \cdot \mathrm{L}^{-1} \mathrm{NAA}$ respectively, while in the presence of $0.4 \mathrm{mg}^{-\mathrm{L}^{-1}} \mathrm{Kin}$, a maximum of $48.5 \%$ plantlets produce microtubers with 40 g. $\mathrm{L}^{-1}$ sucrose (Table 5). With all concentrations of sucrose tested in the presence of NAA and Kin used sparely, the number of microtubers per plantlets varied from 1 to 4 , while in the presence of NAA/Kin, a maximum of 5 microtubers per plantlet was obtained with 30 and 40 g.L 1 sucrose (Table 5). The largest microtubers (130.4 to $131.8 \mathrm{~mm}$ of diameter) were obtained with 40 and 30 $\mathrm{mg} \cdot \mathrm{L}^{-1}$ sucrose respectively in the presence of NAA/Kin compared to other treatments (Table 5). Also with 40 and 
Table 4. Effect of NAA, Kin and NAA/Kin ratio on the production and growth of microtubers from plantlets of Manihot esculenta after 65 days of culture.

\begin{tabular}{|c|c|c|c|c|}
\hline \multirow{2}{*}{$\begin{array}{l}\text { Phytohormones } \\
\left(\mathrm{mg} \cdot \mathrm{L}^{-1}\right)\end{array}$} & \multirow{2}{*}{$\begin{array}{l}\text { \% of plantlets } \\
\text { producing } \\
\text { microtuber }\end{array}$} & \multicolumn{3}{|c|}{ Growth of microtubers } \\
\hline & & $\begin{array}{c}\text { Number per } \\
\text { plantlets }\end{array}$ & $\begin{array}{c}\text { Average diameter } \\
(\mathrm{mm})\end{array}$ & $\begin{array}{c}\text { Average fresh } \\
\text { weight (mg) }\end{array}$ \\
\hline \multicolumn{5}{|l|}{ NAA } \\
\hline 0 & 0 & 0 & 0 & 0 \\
\hline 0.1 & $22.4^{b}$ & $2^{b}$ & $30.2^{c}$ & $151.2^{f}$ \\
\hline 0.2 & $21.8^{c}$ & $2^{b}$ & $56.9^{\mathrm{a}}$ & $248.3^{a}$ \\
\hline 0.3 & $21.7^{\mathrm{c}}$ & $3^{a}$ & $41.7^{b}$ & $219.7^{c}$ \\
\hline 0.4 & $34.6^{\mathrm{a}}$ & $3^{a}$ & $55.8^{\mathrm{a}}$ & $233.4^{b}$ \\
\hline 0.5 & $21.4^{\mathrm{c}}$ & $2^{b}$ & $55.8^{\mathrm{a}}$ & $201.2^{\mathrm{e}}$ \\
\hline 0.6 & $8.1^{\mathrm{d}}$ & $2^{b}$ & $42.6^{b}$ & $213.6^{d}$ \\
\hline \multicolumn{5}{|l|}{ Kin } \\
\hline 0 & 0 & 0 & 0 & 0 \\
\hline 0.1 & 0 & 0 & 0 & 0 \\
\hline 0.2 & $12.3^{d}$ & $1^{d}$ & $38.3^{d}$ & $198.2^{d}$ \\
\hline 0.3 & $24.7^{b}$ & $3^{b}$ & $47.8^{b}$ & $248.6^{\mathrm{b}}$ \\
\hline 0.4 & $33.6^{a}$ & $4^{a}$ & $61.3^{a}$ & $284.1^{a}$ \\
\hline 0.5 & $14.1^{c}$ & $2^{c}$ & $46.1^{c}$ & $218.8^{c}$ \\
\hline 0.6 & $12.4^{d}$ & $2^{c}$ & $38.1^{d}$ & $195.6^{\mathrm{e}}$ \\
\hline \multicolumn{5}{|l|}{ NAA/Kin } \\
\hline 0 & 0 & 0 & 0 & 0 \\
\hline $0.1 / 0.4$ & $6.2^{\mathrm{e}}$ & $2^{c}$ & $30.3^{f}$ & $154.1^{f}$ \\
\hline $0.2 / 0.4$ & $24.8^{d}$ & $3^{b}$ & $56.7^{d}$ & $242.8^{d}$ \\
\hline $0.3 / 0.4$ & $26.9^{c}$ & $4^{a}$ & $101.2^{b}$ & $320.4^{b}$ \\
\hline $0.4 / 0.4$ & $57.6^{a}$ & $4^{a}$ & $108.4^{a}$ & $326.9^{a}$ \\
\hline $0.5 / 0.4$ & $39.3^{b}$ & $2^{c}$ & $58.3^{c}$ & $277.3^{c}$ \\
\hline $0.6 / 0.4$ & $3.2^{f}$ & $3^{b}$ & $48.9^{e}$ & $201.2^{\mathrm{e}}$ \\
\hline
\end{tabular}

DMRT was used to differentiate the percentage of plantlets production microtubers, the number of microtubers per plantlet, the average diameter of microtubers and average fresh weight of microtubers. Data carrying the same letter in the same column were not significantly different at $5 \%$ level.

Table 5. Effect of sucrose on the production and growth of microtubers from plantlets of $M$. esculenta after 65 days of culture.

\begin{tabular}{lccccc}
\hline Phytohormones & $\begin{array}{c}\text { Sucrose } \\
\left(\mathbf{g} \cdot \mathbf{L}^{-1}\right)\end{array}$ & $\begin{array}{c}\text { \% of plantlets } \\
\text { producing } \\
\text { microtubers }\end{array}$ & $\begin{array}{c}\text { Average number of } \\
\text { microtubers per } \\
\text { plantlets }\end{array}$ & $\begin{array}{c}\text { Average diameter } \\
\text { of microtubers } \\
(\mathbf{m m})\end{array}$ & $\begin{array}{c}\text { Average of fresh } \\
\text { weight of microtuber } \\
(\mathbf{m g})\end{array}$ \\
\hline & 0 & 0 & 0 & 0 & 0 \\
& 10 & 0 & 0 & 0 & 0 \\
$\mathrm{NAA}$ & 20 & $39.4^{\mathrm{b}}$ & $3^{\mathrm{a}}$ & $55.6^{\mathrm{a}}$ & $234.6^{\mathrm{a}}$ \\
$\left(0.4 \mathrm{mg} \cdot \mathrm{L}^{-1}\right)$ & 30 & $41.2^{\mathrm{a}}$ & $3^{\mathrm{a}}$ & $52.8^{\mathrm{b}}$ & $229.8^{\mathrm{b}}$ \\
& 40 & $28.4^{\mathrm{c}}$ & $2^{\mathrm{b}}$ & $40.3^{\mathrm{d}}$ & $216.4^{\mathrm{c}}$ \\
& 50 & $11.3^{\mathrm{d}}$ & $1^{\mathrm{c}}$ & $39.9^{\mathrm{d}}$ & $212.3^{\mathrm{d}}$ \\
& 60 & $2.6^{\mathrm{e}}$ & $1^{\mathrm{c}}$ & $41.0^{\mathrm{c}}$ & $202.9^{\mathrm{e}}$ \\
& & & & & 0 \\
$\mathrm{Kin}$ & 0 & 0 & 0 & 0 & $217.6^{\mathrm{d}}$ \\
$\left(0.4 \mathrm{mg} \cdot \mathrm{L}^{-1}\right)$ & 10 & $3.2^{\mathrm{f}}$ & $2^{\mathrm{c}}$ & $49.1^{\mathrm{c}}$ & $288.3^{\mathrm{a}}$ \\
& 20 & $33.7^{\mathrm{b}}$ & $4^{\mathrm{a}}$ & $62.1^{\mathrm{a}}$ & $275.9^{\mathrm{b}}$ \\
& 30 & $32.8^{\mathrm{c}}$ & $3^{\mathrm{b}}$ & $58.6^{\mathrm{b}}$ & $221.8^{\mathrm{c}}$ \\
\hline
\end{tabular}


Table 5. Contd

\begin{tabular}{|c|c|c|c|c|c|}
\hline & 50 & $21.4^{d}$ & $2^{c}$ & $30.9^{e}$ & $161.4^{f}$ \\
\hline & 60 & $9.5^{\mathrm{e}}$ & $2^{c}$ & $43.4^{d}$ & $198.7^{\mathrm{e}}$ \\
\hline \multirow{7}{*}{$\begin{array}{l}\text { NAA/Kin } \\
\left(0.4 / 0.4 \mathrm{mg} \cdot \mathrm{L}^{-1}\right)\end{array}$} & 0 & 0 & 0 & 0 & 0 \\
\hline & 10 & $12.2^{\mathrm{e}}$ & $3^{c}$ & $98.3^{d}$ & $297.8^{d}$ \\
\hline & 20 & $57.8^{b}$ & $4^{b}$ & $109.2^{C}$ & $372.4^{c}$ \\
\hline & 30 & $61.3^{a}$ & $5^{a}$ & $131.8^{a}$ & $408.1^{a}$ \\
\hline & 40 & $40.4^{c}$ & $5^{a}$ & $130.4^{b}$ & $403.3^{b}$ \\
\hline & 50 & $26.2^{d}$ & $1^{d}$ & $91.8^{\mathrm{e}}$ & $286.9^{\mathrm{e}}$ \\
\hline & 60 & $11.7^{\mathrm{e}}$ & $1^{d}$ & $1.3^{f}$ & $249.2^{f}$ \\
\hline
\end{tabular}

DMRT was used to differentiate the percentage of plantlets production microtubers, the average number of microtubers per plantlet, the average diameter of microtubers and the average fresh weight of microtubers per plantlets. Data carrying the same letter in the same column were not significantly different at $5 \%$ level.

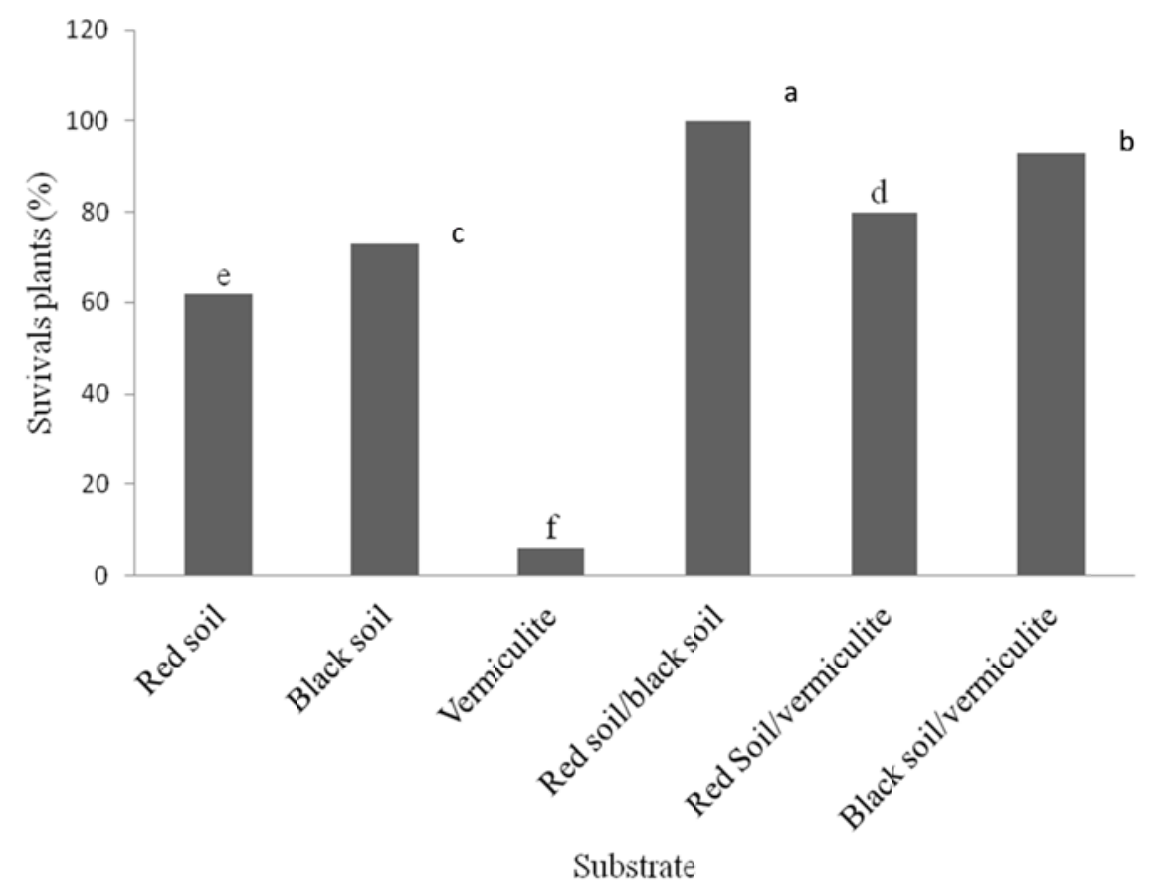

Figure 3. Effect of substrate on the acclimatization of plantlets regenerated from multiples shoot of $M$. esculenta after 36 days. DMRT was used to differentiate the percentage of survival plants on different substrates share carrying the same letter were not significantly different at $5 \%$ level.

$30 \mathrm{mg} \mathrm{L}{ }^{-1}$ sucrose and in the presence of $0.4 / 0.4 \mathrm{mg} \cdot \mathrm{L}^{-1}$ NAA/Kin, microtubers presented the highest fresh weights of $403.3 \mathrm{mg}$ and $408.1 \mathrm{mg}$, respectively compared to all other treatments (Table 5).

\section{Effect of substrate on the acclimatization of plantlets}

When transferred on different substrates, the plantlets regenerated from shoots gave rise to vigorous plants after 36 days. During this period, each surviving plant had an average height of $19.8 \pm 1.7 \mathrm{~m}$ and average number of existing leaves of 14.6. The percentages of surviving plants varied with the type of substrate. In fact, a significant percentage of $100 \%$ of survival plants was exposed to mixture red soil/black soil (V/V), followed by a mixture of black soil/vermiculite (v/v) (93\%), a mixture of red soil/vermiculite (V/V) (80\%). The red soil and black soil gave average percentages of surviving plants (62 to $73 \%$ ) and vermiculite gave the lowest percentage of $6 \%$ (Figure 3). 


\section{DISCUSSION}

Manihot esculenta as many tropical crops can be successfully propagated in vitro. Different explants such as nodal cuttings (Konan et al., 1997; Smith et al., 1986), meristems (Kartha et al., 1974), auxiliary buds (Konan et al., 1994), shoot-tips (Roca et al., 1992) can be used for this propagation. The propagation of Manihot esculenta can be direct by inducing shoots directly from the explants or indirectly by inducing shoot from the callus. This has been obtained in the same species by Acedo and Labana (2008); Ma and Xu (2002) or in other species such as Saussurea obvaiiata (Dhar and Joshi, 2005), Dioscorea zingiberensis (Yongqin et al., 2003; Yuan et al., 2005), Dioscorea alata (Fotso et al., 2013) and Colocassia esculenta (Yam et al. 1990; 1991). The nodal cuttings when cultured on MS supplemented with BAP or NAA budded after 11 days with higher percentages of $98 \%$ (0.07 $\left.\mathrm{mg} \mathrm{l}^{-1} \mathrm{BAP}\right)$ and $73 \%$ (0.05 $\left.\mathrm{mg} \mathrm{l}^{-1} \mathrm{NAA}\right)$. Comparable results have been showed in many herbaceous and ligneous species (Blagwat et al., 1996; Gulati and Jaiwal, 1996; Fotso, 2005). But in general, the rate of budding varies not only according to the species but also according to the nature and the concentration of phytohormone used. The results of this work show that BAP is more effective on budding (98\%) than NAA $(73 \%)$. Similar results were obtained on tree varieties of the same species by Deden and Herni (2011) but with the combination of thidiazuron. In this work, the callus of Manihot esculenta was induced from budded nodal cuttings in the presence of NAA. Many works have been carried out on the establishment of callus culture from cassava using different explants (Peter et al., 2011; Fietosa et al., 2007; Atehnkeng et al., 2005; Schopke et al., 1996), but this is the first time that callus is established from budded nodal cutting of this species. The highest percentage of callogenesis $(59.8 \%)$ was obtained with $0.08 \mathrm{mg}^{-\mathrm{L}^{-1}} \mathrm{NAA}$.

Similar results were obtained by Peter et al. (2011) on two cultivars of the same species of cassava (cv Afisiati and cv Afebankye) but with higher concentration of NAA ( 8 to $15 \mathrm{mg}^{-1}$ ). The shoots of cassava were induced directly from budded nodal cuttings or indirectly from callus in the presence of BAP. This confirms the highest potential of BAP to induce shoots in different species as reported in several works (Anh Hong et al., 2007; Konan et al., 1997; Fotso et al., 2013; Davies, 2004). The percentages of explants inducing shoots were ranged from $12.4 \%$ (0.06 mg. ${ }^{-1}$ BAP) to $72.3 \%$ (0.08 mg. $\mathrm{L}^{-1}$ BAP) for nodal cuttings and from $13.3 \%$ (0.05 mg. $\mathrm{L}^{-1}$ BAP) to $92.3 \%$ (0.08 mg. L $^{-1}$ BAP) for callus. Also with the same concentrations of BAP, the average numbers of shoots per explants were ranged from 3.2 to 17.9 for nodal cuttings and from 4.0 to 28.1 for callus. Then in the presence of BAP, callus of Manihot esculenta seem to be more effective to induce shoots than nodal cuttings. These results are comparable to those obtained by
Deden and Herni (2011) on three cassava varieties but BAP was used in combination with 0.1 to $1 \mathrm{mg} \cdot \mathrm{L}^{-1}$ thidiazuron and $80 \mathrm{mg} \cdot \mathrm{L}^{-1}$ adenine sulfate. In this work, plantlets were regenerated when shoots were subcultured in the presence of different ratio BAP/NAA. With the ratio $0.07 / 0.05$ and $0.08 / 0.05 \mathrm{mg} . \mathrm{L}^{-1}$, all shoots $(100$ $\%$ ) gave rise to plantlets with the highest growth parameters The regeneration of plantlets in the presence of BAP/NAA ratio was already reported in the same specie (Ma and $\mathrm{Xu}, 2002$ ) or in the other species (Mantell and Hugo, 1989; Fotso et al., 2013; Dhar and Joshi, 2005).This result confirms the complementary and synergize action of auxins and cytokinins in the process of growth and development that has been reported by some authors (Dhar and Joshi, 2005; Vines, 2001; Guo and Zhang, 2005).When acclimatized, plantlets regenerated from Manihot esculenta survived more $(100 \%)$ in the mixture red soil/black soil $(\mathrm{V} / \mathrm{V})$. This result is in contrasts with acclimatization of many species where plantlets survived in vermiculite or in mixture of vermiculite and soil (Yongqin et al., 2003; Yassen et al., 1995).

In this study, the microtubers were produced when the basal medium was supplemented with $2 \mu \mathrm{M}$ jasmonic acid different concentration of NAA, Kin, NAA/Kin ratio and sucrose. Till date very few works has been reported on microtuberization in cassava species while several has been reported on other crop tuber species such as Solanum tuberosum (Gami et al., 2013; El-Sawy et al., 2007), Xanthosoma sagittifolium (Tsafack et al., 2009), Dioscorea sp (Ovono Ondo et al., 2007; Fotso et al., 2013). These different works show that, the percentage of plantlets producing microtubers, the number of microtubers per plantlet and their size varies not only according to species but also according to the culture conditions and this is confirmed in this study. In fact, jasmonic acid has been shown to be effective on microtuberization (Santos and Salema, 2000), but this effectiveness also depend on the other culture conditions mainly the type and the concentration of phytohormones used and the concentration of sucrose in the culture media (Hoque, 2010; Yu et al., 2000; Zakaria et al., 2008; Bazabakana et al., 2003). The results of this study shows that, microtubers in Manihot esculenta can be produced in the presence of $2 \mu \mathrm{M}$ jasmonic acid and 0.1 to 0.6 mg. $\mathrm{L}^{-1} \mathrm{NAA}$ or Kin used separately or in ratio (NAA/Kin).

The highest percentages of plantlets producing microtuber were $34.6 \%\left(0.4 \mathrm{mg} . \mathrm{L}^{-1} \mathrm{NAA}\right), 33.6 \%(0.4$ $\left.\mathrm{mg} . \mathrm{L}^{-1} \mathrm{Kin}\right)$ and $57.6 \%\left(0.4 / 0.4 \mathrm{NAA} / \mathrm{Kin} \mathrm{mg} \cdot \mathrm{L}^{-1}\right)$. With these concentrations the highest number of 3 and 4 microtubers was obtained with the respective diameter of $55.8 \mathrm{~cm}, 61.3 \mathrm{~cm}$ and $108 \mathrm{~cm}$ and the respective fresh weight of $233.4 \mathrm{mg}, 248.1 \mathrm{mg}$ and $326.9 \mathrm{mg}$ for NAA, Kin and NAA/Kin. Then, NAA and Kin were more effective on the microtuberization in Manihot esculenta when they were used in ratio or combination. These results were comparable to those obtained by Tsafack et al. (2009) in Xanthosoma sagittifolium during which the effect of 
photoperiod and thermoperiod were also studied on the microtuberilization, but are in contrast with those obtained by Gami et al. (2013) which showed that NAA or Kin used separately were more effective on the microtuberilization in Solanum tuberosum. When the basal medium is supplemented with 10 to $60 \mathrm{~g} \mathrm{I}^{-1}$ sucrose and $0.4 \mathrm{mg} \mathrm{I}^{-1}$ NAA or Kin or $0.4 / 0.4 \mathrm{mg} \mathrm{I}^{-1} \mathrm{NAA} / \mathrm{Kin}$, the highest percentage of plantlets producing microtubers $(61.3 \%)$ the highest numbers of microtubers per plantlet (5) having bigger sizes $(131.8 \mathrm{~cm}$ of diameter and $408.1 \mathrm{mg}$ of fresh weight) were obtained with NAA/Kin ratio and $30 \mathrm{~g} . \mathrm{L}^{-}$ ${ }^{1}$ sucrose. This result contrasts those obtained by Debeljak et al. (2002) in Pterostylis sanguinea which showed that in the presence of 1.5 and $2 \mathrm{mM}$ jasmonic acid and NAA or Kin the microtuberization is induced at least with 60 g. $\mathrm{L}^{-1}$ sucrose, and those of Alizadeh et al. (1998) which show that in Dioscorea composita, microtuberilization is induced with 80 to $100 \mathrm{mg}^{\mathrm{L}} \mathrm{L}^{-1}$ sucrose.

\section{Conclusion}

Direct and indirect organogenesis of $M$. esculenta was achieved in this study from micro cuttings and induced callus cultured in the presence of BAP and NAA. Plantlets were fully regenerated when these phytohormones were used in combination or ratio with $100 \%$ of success with ratio BAP/NAA of $0.07 / 0.05$ and $0.08 / 0.05$ $\mathrm{mg} \cdot \mathrm{L}^{-1}$. Microtuberization was induced on regenerated plantlets in the presence of NAA, Kin and 10 to $60 \mathrm{~g}^{-\mathrm{L}^{-1}}$ sucrose. $100 \%$ of regenerated plantlets survived when acclimatized in a mixture of red soil/black soil. Hence, the micropropagation of $M$. esculenta by in vitro culture method is more effective and more significant than the conventional method where apex culture produced generally a single plant. Further studies are needed to evaluate the performance of plantlets transferred to the fields.

\section{Conflict of Interests}

The author(s) have not declared any conflict of interests.

\section{ACKNOWLEDGMENT}

The authors thank the team of Biology Laboratory of HTTC, The University of Bamenda and the team of Laboratory of Plant Physiology and Biochemistry (LAF 314), ENS Yaoundé Cameroon for their collaboration.

\section{REFERENCES}

Acedo VZ, Labana C (2008). Rapid propagation of released Philippine cassava varieties through tissue culture. J. Root Crops 34(2):108-14.

Albert CL, Klanarong S, Tzou-chi H (2005). Proximate composition, mineral contents, hydrogen cyanide and phytic acid of 5 cassava genotypes. Food Chem. 92:615-620
Alizadeh S, Mantell SH, Viana AM (1998). In vitro shoot culture and microtuber induction in the steroid yam Dioscorea composita Hemsl. Plant Cell Tissue Organ Cult. 53:107-112.

Anh Hong LT, Le BV, Anh BL, Soytong K, Danh ND (2007). Plant regeneration of cassava (Manihot esculenta CRANTZ) plants. J. Agric. Technol. 3(1):121-127.

Atehnkeng J, Adetimirin VO, Ng SYC (2005). Exploring the African cassava (Manihot esculenta Crantz) germplasm for somatic embryogenic competence. Afr. J. Biotechnol. 5:1324-1329.

Bazabakana R, Baucher M, Diallo B, Jaziri M (2003). Effect of jasmonic acid on developmental morphology during in vitro tuberisation of Dioscorea alata. Plant Growth Regul. 40:229-237.

Bhagwat B, Luiz, GF, Vieiral and Larry R, Erickson (1996). Stimulation of in vitro shoot proliferation from nodal explants of cassava by thidiazuron, benzyladenine and gibberellic acid. Plant Cell Tissue Organ Cult. 46:1-7.

Davies PJ (2004). The plant hormones: Their Nature, Occurrence and Function In: Davies PJ (Editor) Plant Hormones Biosynthesis, Signal Transduction, Action. Kluwer Academic Press. 1-15

Debeljak N, Regvar M, Dixon KW, Sivasithamparam K (2002). Induction of tuberization in vitro with jasmonic acid and sucrose in an Australian terrestrial orchid, Pterostylis sanguinea. Plant Growth Regul. 36:253260.

Deden S, Herni W (2011). Effects of plant growth regulators on shoot multiplication and root induction of cassava varieties in vitro culture. Biotropia 18 (1): 50 - 60.

Dhar U, Joshi M (2005). Efficient plant regeneration protocol through callus for Saussurea obvallata (DC.) Edgew. (Asteraceae): effect of explant type, age and plant growth regulators. Plant Cell Rep. 24: 195-200.

El-sawy A, Bekhetet S, Aly UI (2007). Morphological and molecular characterization of potato microtubers production on coumarin inducing medium. Int. J. Agric. Biol. 9 (5):675-680.

Fietosa T, Bastos JLP, Ponte LFA, Jucá TL, Campos F (2007). Somatic Embryogenesis in Cassava Genotypes from the Northeast of Braz. Arch. Biol. Technol. 50:201-206.

Fotso (2005). In vitro organogenesis of some wild plants at multiple uses. Ph D Thesis, UYI Cameroon. $160 \mathrm{p}$.

Fotso, Ngo Ngwe MFS, Mbouobda HD, Djocgoue PF, Omokolo ND (2013). Micropropagation of Dioscorea alata L. from microtubers induced in vitro. Afr. J. Biotechnol. 12 (10): 1057-1067.

Gami RA, Parmar SK, Patel PT, Tank CJ, Chauhan RM, Bhadauria HS Solanki SD (2013). Microtuberization, minitubers formation and in vitro shoot regeneration from bud sprout of potato (Solanum tuberosum L.) cultivar K. badshah. Afr. J. Biotechnol. 12(38):56405647.

Gulati A, Jaiwal PK (1996). Micropropagation of Dalbergia sissoo from nodal explants of mature trees. Biol. Plantarum. 3(2):169-175.

Guo Y, Zhang Z (2005). Establishment and plant regeneration of somatic embryogenic cell suspension cultures of the Zingiber officinale Rosc. Sci. Hortic. 107: 90-96.

Hoque ME (2010). In vitro tuberization in potato (Solanum tuberosum L.). Plant Omics J. 3(1):7-11.

Kartha KK, Gamborg OL, Constabel F, Shyluk JP (1974). Regeneration of cassava plants from apical meristems. Plant Sci. Lett. 2:107-113.

Koda Y, Kikuta Y (1991). Possible involvement of jasmonic acid in tuberization of yam plants. Plant Physiol. 32:629-633.

Konan NK, Chopke C, Carcamo R, Beachy RN, Fauket C (1997). An efficient mass propagation system for cassava (Manihot esculenta Crantz) based on nodal explants and axilarry bud-deived meristem. Plant Cell Rep. 16:444-449.

Konan NK, Sangwan RS, Sangwan-Norreel BS (1994). Efficient in vitro shoot-regeneration systems in cassava (Manihot esculenta Crantz). Plant Breed. 113:227-236.

Ma GH, Xu QS (2002). Induction of somatic embryogenesis and adventitious shoots from immature leaves of cassava. Plant Cell Tissue Organ Cult. 70:281-282.

Mantell SH, Hugo SA (1989). Effects of photoperiod, mineral medium strength, inorganic ammonium, sucrose and cytokinin on root, shoot and microtuber development in shoot culture of Dioscorea alata L. and $D$. bulbifera L. yams. Plant Cell Tissue Organ Cult. 16:23-37.

Morel G, Wetmore RH (1951). Fern callus tissue culture. Ann. J. Bot. 
38:141-143.

Murashige T, Skoog F (1962). A revised medium for rapid growth and bioassays with tobacco tissue cultures. Plant Physiol. 15:473-479.

Ovono Ondo P, Kevers C, Dommes J (2007). Axillary proliferation and tuberisation of Dioscorea cayenensis $-D$. rotundata complex. Plant Cell Tissue Organ Cult. 91:107-114.

Peter T, Eugene KAF, Amoako TNE (2011). Effect of 2.4-D, explants type and cultivar on the callogenesis expression of cassava (Manihot esculenta Crantz) in Ghana. Afr. J. Biotechnol. 10 (46): 9396-9401.

Rani V, Raina SN. (2000). Genetic Fidelity of Organized MeristemDerived Micropropagated Plants: A Critical Reappraisal. In Vitro Cell Dev. Biol. Plant 36(5):319-330.

Roca WM, Henry G, Angel F, Sarria R (1992). Biotechnology research applied to cassava improvement at the International Center of Tropical Agriculture (CIAT). 8-15.

Santos I, Salema R (2000). Promotion by jasmonic acid of buld formation in shoot culture of Narcissus triandus L. Plant Growth Regul. 30:133-138.

Schopke C, Taylor N, Carcamo R, Konan NDK, Marmey P, Henshaw GG, Beachy RN, Fauquet C (1996). Regeneration of transgenic cassava plants (Manihot esculenta Crantz) from microbombarded embryogenic suspension cultures. Nat. Biotechnol. 14:731-735.

Smith MK, Biggs BJ, Scott KJ (1986). In vitro propagation of cassava (Manihot esculenta Crantz). Plant Cell Tissue Organ Cult. 6:221-228.

Taylor NJ, Edwards M, Kiernan RJ, Davey CDM, Blakesley D. Henshaw GG (1996). Development of friable embryogenic callus and embryogenic suspension culture systems in cassava (Manihot esculenta Crantz). Nat. Biotechnol. 14:726-730.

Tsafack TJJ, Charles GP, Hourmant A, Omokolo ND, Branchard M (2009). Effect of photoperiod and thermoperiod on microtuberization and carbohydrate levels in cocoyam (Xanthosoma sagittifolium (L.) Schott). Plant Cell Tissue Organ Cult. 96:151-159.
Vines R (2001). Plant Biotechnology. Biotechnology Information, Virginia Tech. p. 443.

Whingwiri E (2004). NEPAD Pan Africa Cassava Initiative. Paper read at ISTRC-AB Symposium, $31^{\text {st }}$ October-5th November 2004, Whitesands Hotel, Mombasa, Kenya.

White WLB, Arias-Garzon DI, McMahon JM, Sayre RT (1998). Cyanogenesis in Cassava - The Role of Hydroxynitrile Lyase in Root Cyanide Production. Plant Physiol. 116:1219-1225.

Yam TW, Ishihashi S, Arditti J (1991). Callus growth and plantlet regeneration in taro, Colocassia esculenta var esculenta (L.). Ann. Bot. 67:317-323.

Yam TW, Webb EL, Arditti J (1990). Callus formation and plantlet development from axillary buds of taro. Planta 180: 458-460.

Yassen RN, Shell RJ, Splittstoesser WE (1995). In vitro shoot proliferation and micropropagation of guava (Psidium guajava L.) from germinated seedlings. Plant Cell Rep. 14:525-528.

Yongqin C, Jinyu F, Fei Y, Zhongxun L, Yunsheng F (2003). Rapid clonal propagation of Dioscorea zingiberensis. Plant Cell Tissue Organ Cult. 73:75-80.

Yu WC, Joyce PJ, Cameron DC, McCown BH (2000). Sucrose utilization during potato microtuber growth in bioreactors. Plant Cell Rep. 19:407-413.

Yuan S, Yan Y-C, Lin H-H (2005). Plant regeneration through somatic embryogenesis from callus cultures of Dioscorea zingiberensis. Plant Cell Tissue Organ Cult. 80:157-161.

Zakaria M, Hossain M M, Khalequemain M A, Hossain T, Uddin M Z (2008). In vitro tuberization of potato influenced by Benzyl Amino Purine (BAP) and Chloro chloline chloride (CCC). Bangladesh J. Agric. Res. 33(3):419-425. 